\title{
Insubordination: Central issues and open questions
}

\author{
Karin Beijering, Gunther Kaltenböck, María Sol Sansiñena
}

\section{Introduction: A brief history of insubordination}

The past decade has witnessed an ever-increasing interest in insubordination and related phenomena, particularly since the appearance of Evans' (2007) seminal paper 'Insubordination and its uses'. Since then, numerous studies have been published on various types of insubordinate constructions in a wide variety of typologically different languages from different analytical perspectives (see especially Evans and Watanabe 2016a and references therein).

What makes insubordination so intriguing is that it presents a challenge for traditional grammatical frameworks owing to its ambivalent, Janus-like appearance, which combines subordinate structure with main clause function. This dual nature is neatly summarized in Evans's definition, which has by now become accepted currency in the field: "the conventionalized main clause use of what, on prima facie grounds, appear to be formally subordinate clauses" (Evans 2007: 367). ${ }^{1}$ An insubordinate clause thus has the appearance of a subordinate clause, but has been reanalysed as a main clause. It is in this subordinate form that insubordination differs from nonsubordination (de Vries e.g. 2007), which is described as a strategy of paratactic text planning that includes parenthesis, apposition, coordination, juxtaposition and hedging. ${ }^{2}$ Some illustrative examples of insubordination are given in (1) to (4).

(1) ENGLISH (ICE-GB:s1a-089-159)

If you'll just come next door.

(2) SWEDISH (D'Hertefelt 2015: 23, IC)

https://issuu.com/danielheiniemi/docs/o4u05_tr/19)

Att du aldrig kan passa tider!

COMP you never can.PRS watch.INF times

'Why can't you ever keep track of the time!'

(lit.: That you never can watch the time!)

(3) SPANISH (MABPE2-01b, COLA M)

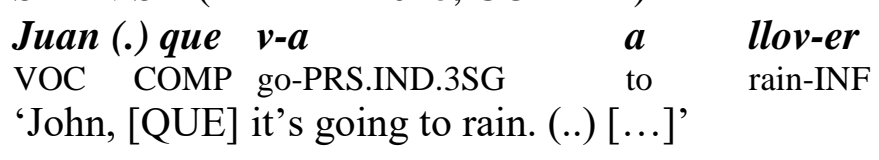

\footnotetext{
${ }^{1}$ This is a refined version of an earlier definition given in Evans (1988: 255), which identified insubordination as "the use of a formally subordinate clause type as a main clause".

${ }^{2}$ De Vries defines nonsubordination as "parataxis in the broad sense. It means the equipollent ranking of clauses or constituents: if $\beta$ is paratactically construed with respect to $\alpha, \beta$ is not subordinated to $\alpha$, and $\beta$ does not restrict the meaning of $\alpha$; rather it adds information to $\alpha$." (de Vries 2007: 203; n.d.); cf. in this context also Heine et al.'s (2016) notion of "theticals".
} 
(4) JAPANESE (Evans 2009:1)

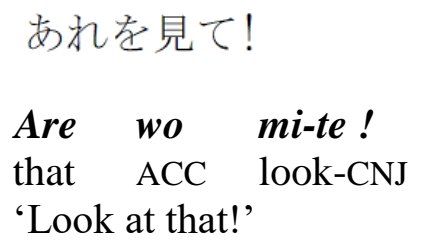

As can be seen from the examples, insubordinate clauses have all the formal cues of subordinate clauses. These are, for instance, subordinators, infinitive, participal or subjunctive inflections on the verbs, subordinate clause word order, depending on the language-specific markers of subordination. What is absent, however, is a matrix clause. Instead, they are - at least in their prototypical forms - stand-alone structures as a result of their reanalysis over time as conventionalized independent constructions. Insubordination thus has an inherent diachronic side to it. Insubordinate clauses may look like subordinate clauses but to the extent that they adopt main clause use "the term 'subordinate' means, at best, 'having diachronic origins as a subordinate clause'" (Evans 2007: 370). As such, they straddle the boundary between syntactic structure (mental representation) and actual language use (see Section 2).

The motivation for subordinate clauses becoming conventionalized as independent structures lies in their adoption of specialized discourse functions. A number of different functions have been identified for insubordinate clauses, for instance the expression of requests, epistemic, evidential and deontic meaning, exclamations, evaluations, and contrastive focus (e.g. Evans 2007; see Section 4 for further discussion). In the examples above, for instance, (1) expresses a request, (2) an evaluation, (3) a warning, and (4) a command/request. Despite the range of different pragmatic possibilities, the functions of insubordination are still relatively constrained in that they typically involve the expression of interpersonal relations such as the expression of speaker attitudes and the management of speaker-hearer interactions (e.g. Van linden and Van de Velde 2014: 228; Sansiñena, De Smet and Cornillie 2015a: 16; Heine, Kaltenböck and Kuteva 2016).

Although the interest in insubordination has been sparked only recently, mainly by Evans' (2007) first systematic study, the phenomenon did not go completely unnoticed before. Some of these notable exceptions include Buscha's (1976) study of isolierte Nebensätze 'isolated subordinate clauses' and Weuster's (1983) study of nicht-eingebettete Nebensätze 'non-embedded subordinate clauses' for German, and Ohori's (1996, 2000) study of chuudansetsu 'suspended clauses' for Japanese. It was particularly in the Romance languages that insubordination has received some attention, for instance Schwenter's (e.g. 1996, 1999) investigation of independent si-clauses in Spanish (cf. also Almela Perez 1985; Montolío 1999; Gras 2011), Lombardi Vallauri's (2003, 2004) study of ipotetiche sospese 'suspended hypotheticals' and 'free conditionals' in Italian, and Debaisieux's (2006) discussion of subordonées sans principales 'subordinates without main clauses' in French (cf. also Deulofeu 1988, 1999). ${ }^{3}$ In English, the focus has been mainly on what Stirling (1998) calls "isolated ifclauses" (cf. also Ford and Thompson 1986; Ford 1997; Declerck and Reed 2001). Other studies relate to smaller languages such as Evans' (e.g. 1988) earlier work on the Australian Kayardild language and Mithun's (2008) work on the North American languages Yu'pik and Navajo.

\footnotetext{
${ }^{3}$ For Spanish Evans (2007: footnote 3) also notes an early mention of insubordination in Bello (1847).
} 
As can be seen from the brief overview above, the phenomenon of insubordination has been discussed under various different guises. Other terms used to refer to it include, for instance, "independent conditional clause" (e.g. D'Hertefelt 2013), "free conditional" (e.g. Lombardi Vallauri 2004, 2010), "suspended clause" (e.g. Ohori 1996), "stand-alone nominalization" (e.g. Yap et al. 2011), and "de-subordination" (Givón 2015: 661-691). Although some of these terms may be more accurate, the present volume has adopted Evans' "insubordination" as it has by now become the most established term. It also conveniently highlights the process nature of the phenomenon and captures its 'unruliness' in terms of fitting into traditional grammatical frameworks.

It is precisely this 'unruliness' which makes it fall outside the moulds of traditional grammar that can be seen as responsible for the lack of attention insubordination has received in grammatical descriptions. This is true even for the reference grammars of well-described languages such as Latin, Classical Greek and English (as noted by Evans and Watanabe 2016b: 19). As a clause type which does not meet the criteria of completeness of written syntax, insubordinate clauses were either ignored in earlier linguistic work or marginalized as anomalies (see Section 2).

In recent years, however, insubordination has moved more centre stage. This is in no small amount due to Evans (2007), who has shown insubordination to be far from exceptional but widely attested cross-linguistically. His work has led to a spate of studies which have identified the phenomenon in ever more languages, providing more and more fine-grained descriptions: for instance for Spanish (e.g. Gras 2011, 2013, 2016; Sansiñena, De Smet and Cornillie 2015a, 2015b; Gras and Sansiñena 2015, 2017; Sansiñena 2015, 2017; Elvira-García 2016; Elvira-García et al. 2017), English (e.g. Mato-Míguez 2014a, 2014b, 2014c, 2016; Brinton 2014a, 2014b; Schröder 2016; Kaltenböck 2016), Dutch (e.g. Verstraete, D'Hertefelt and Van linden 2012; Boogaart and Verheij 2013; Boogaart 2015; Beijering 2017), Swedish (e.g. Laury, Lindholm and Lindström 2013; D’Hertefelt and Verstraete 2014; Lindström, Lindholm and Laury 2016), Danish (e.g. D'Hertefelt and Verstraete 2014), Norwegian (e.g. Beijering 2016), Finnish (e.g. Laury 2012; Laury, Lindholm and Lindström 2013; Lindström, Lindholm and Laury 2016), Italian (e.g. Lombardi Vallauri 2010), French (e.g. Patard 2014; Debaisieux, Deulofeu and Martin 2008), German (e.g. Kaiser 2014), Germanic languages more generally (e.g. D'Hertefelt 2018) and various non-Indo European languages (e.g. Cable 2011). This surge of interest in insubordination can, no doubt, also be attributed to the availability of large spoken corpora which allow for the investigation of low-frequency phenomena as well as the development and coming of age of new theoretical frameworks which take into account the emergent and interactional nature of language (see Section 2).

The only book-length treatment of insubordination to date is Evans and Watanabe (2016a), which offers a timely overview of the advances in the field since Evans (2007) and Mithun (2008). The contributions span a wide range of different topics from detailed descriptions of (language-specific) structural and semantic correlates of insubordination (e.g. Mithun [Mohawk], Schwenter [Spanish], Gras [Spanish], Lombardi Vallauri [Italian], Narrog [Japanese], Watanabe [Sliammon]) to insights from discourse and interactional linguistic approaches (e.g. Heine et al. [English], Dwyer [Inner Asian Turko-Mongolic languages], Floyd [Cha'palaa language of Ecuador] and typological overviews of insubordination phenomena (e.g. Evans and Watanabe [Kayardild], Verstraete and D'Hertefelt [Germanic languages], Berge [Aleut], Comrie et al. [Tsezic languages], Robbeets [Transeurasian languages], Cristofaro [cross-linguistic perspective]).

The present volume complements Evans and Watanabe (2016a), in particular with regard to the delimitation of the concept by extending the scope to semi-insubordination and other related constructions. Based on a selection of studies presented in the workshop '(Semi- 
)independent subordinate constructions' at the $48^{\text {th }}$ SLE conference in Leiden, the volume provides an up-to-date overview of current research on the topic. The perspective adopted is a cross-linguistic one which covers a range of different languages (viz. English, Finnish, French, German, Mohawk, Navajo, Old Church Slavonic, Polish, Russian, Spanish, Swedish) and various forms of (semi-)insubordination. By bringing together contributions from different perspectives and theoretical backgrounds, this volume hopes to deepen our understanding not only of individual instances of insubordination, but also of the category as a whole. More specifically, the volume has the following three aims:

(i) To explore how the category of insubordination can be delimited and which different levels of (in)dependence should be distinguished (e.g. syntactic, semantic/pragmatic, dyadic)

(ii) To investigate the grammatical status of insubordinate constructions and how they can be accounted for in a grammatical analysis/model.

(iii) To describe the formal and functional characteristics of specific instances of insubordination, both synchronic and diachronic.

In the remainder of this chapter we will give a brief overview of some of the pertinent topics in the research on insubordination and related structures. Section 2 looks at the question of the grammatical status of insubordinate constructions. Section 3 discusses different possible types of this phenomenon. Section 4 outlines their functional versatility and Section 5 highlights the challenge of insubordination from a diachronic perspective. Section 6, finally, provides an overview of the individual contributions to the volume.

\section{What is their grammatical status?}

As noted above, insubordinate clauses represent a challenge for grammatical representation. They are clearly subordinate in terms of their structure; in terms of their use, however, they are like independent main clauses. This combination of syntactic independence on the one hand and formal signs of subordination (e.g. subordinator, subordinate-clause word order, etc.) on the other is difficult to account for in a grammar. In this sense insubordinate clauses live up to the double-meaning of the term 'insubordination' as highly 'unruly' constructions.

Various attempts have been made in the grammatical literature to come to terms with their ambivalent nature. One approach is to deal with them simply as performance features which involve ellipsis. ${ }^{4}$ The problem with ellipsis-based accounts is, however, that the missing matrix clause is not always fully and unambiguously recoverable from the context (as shown e.g. for if-clauses by Stirling 1998; Lombardi Vallauri 2004; Mato-Míguez 2014a, b). Compare, for instance, the following example, where there is a wide range of possibilities for the reconstruction of a matrix clause (e.g. I'd be grateful, feel free to do so, etc.).

(5) If you'd like to say a few words.

Moreover, an ellipsis approach may be problematic as it fails to account for cases where the subordinate clause has a complete (i.e. terminal) prosodic contour (e.g. Schwenter 2016; ElviraGarcía, this volume; cf. also Kaiser and Struckmeier, this volume), has its own illocutionary

\footnotetext{
${ }^{4}$ Ellipsis-based accounts have also been applied in the domain of generative semantics (e.g. Lakoff 1968).
} 
force, and shows structural signs typical of a main clause such as the ability to coordinate with another main clause or the ability to take a subordinate clause as its dependent (e.g. MatoMíguez 2014a, b). Features such as these suggest that we are not dealing with incomplete structures which are the result of performance 'accidents', but rather with deliberately produced and complete constructions.

When insubordinate clauses are treated as part of the grammar, they are often relegated to its margins and classified as unsystematic, non-canonical patterns, which are somehow incomplete. Quirk et al. (1985: 838ff), for instance, subsume them under so-called "irregular sentences" on account of their "not conform[ing] to the regular patterns of clause structures". Similarly, Huddleston and Pullum (2002: 944) take insubordinate clauses to belong to the category of "minor clause types", which subsumes "a number of main clause constructions that do not belong to any of the major clause types". ${ }^{5}$ However, the notion of incompleteness is tied to our concept of grammar and can be seen as an artefact of grammatical tradition (see Debaisieux et al., this volume; Struckmeier and Kaiser, this volume; Wiemer, this volume; Bergs 2017; Traugott 2017: 294).

The reason why insubordinate clauses have for a long time either been ignored or marginalised by grammatical description is rooted to a large extent in our understanding of grammar itself. Clearly, a phenomenon such as insubordination is difficult to accommodate in a view of grammar which builds on a relatively stative model of competence divorced from performance and which has written language as its main object of interest. Instead, insubordination requires us to rethink certain grammatical assumptions and adopt a more dynamic view of grammar which takes into account spoken interaction in equal measure. More specifically, insubordination is particularly compatible with grammatical models that embrace positions such as the following:

(a) A dynamic link between usage and structure (parole and langue, performance and competence): This is of course the view adopted by the paradigm of usage-based grammar (e.g. Langacker 2000; Haiman 1994; Bybee 2010), which sees linguistic structure as emerging out of actual language usage with constant interaction between these two levels. As a theory of grammar which has gained momentum in recent decades it has undoubtedly provided fertile ground for the investigation of phenomena such as insubordination (see also Kaltenböck, this volume). Evans and Watanabe (2016b: 1) even identify insubordination as "a key site for understanding the dynamic and constant interplay of parole and langue, i.e. of actual spoken data in discourse on the one hand, and grammatical models used by speakers (or grammarians) on the other". This interplay is particularly obvious in the presumed emergence and diachronic development of insubordination (see Section 5), but also synchronically, in the use of insubordinate clauses in interaction (see next point).

(b) The adoption of an interactional perspective: With the rise of corpus linguistics the focus in grammatical investigation has increasingly shifted to spoken language, particularly its interactional use, which is generally seen as the most natural 'habitat' of spoken language. Speech in interaction is, in fact, at the core of many more recent approaches to language, such as Conversation Analysis, Emergent Grammar and Interactional Linguistics, which focus on how utterances are being co-constructed by the participants. In these frameworks insubordination no longer has to be conceptualized in terms of complete complex sentences, as demonstrated for instance by Couper-Kuhlen's (1996) interactional discussion of independent

\footnotetext{
${ }^{5}$ In a similar vein Stirling (1998: 289) identifies insubordinate if-clauses as "minor sentence types".
} 
because-clauses in conversation. Such an interactional perspective is particularly relevant for the analysis of dyadic insubordinations or "collaborative insubordinations" (Hilpert 2015), as in (6), and can provide vital clues for explaining the emergence of the construction, both synchronically and diachronically (e.g. Sansiñena 2015; Sansiñena, De Smet and Cornillie 2015a; Lindström et al., this volume).

(6) SPANISH (YCCQA, Sansiñena et al. 2015a: 4)

A: ¿Qué significa ser racional?

'What does it mean to be rational?'

B: Que distingues entre el bien y el mal creados por un precepto social.

'That you distinguish among good and evil created by a social precept.'

(c) The inclusion of prosody in grammatical description: An extension of grammar to account also for all types of spoken language, including its interactional forms, naturally entails a foregrounding of the role of prosody. All too often, however, prosody is still seen as a mere appendage to grammatical description rather than an integral part of grammatical constructions as one of the formal means that signal meaning. The study of insubordination thus serves as an important reminder of the role of prosody for a comprehensive grammatical description. In fact, prosody has been shown to be a crucial factor in distinguishing insubordinate clauses from regular subordinate clause (e.g. Gras 2011, 2016; Schwenter 1996, 1999, 2016; Debaisieux 2006; Debaisieux, Deulofeu and Martin 2008; Lombardi Vallauri 2016; Kaltenböck 2016; Elvira-García, this volume) with cases of prosodic ambiguity being centrally involved in the emergence of insubordination.

The concept of insubordination thus challenges our understanding of grammar on a number of different levels. It reminds us, in particular, of the necessity to conceptualize grammar not only as an inventory of stored, more or less conventionalized linguistic units, but also as an activity, used for designing utterances in a given situation. As noted by Evans and Watanabe (2016b: 2), insubordinate clauses "lie at the threshold of process and product, or energeia and ergon". To capture this dual process-product nature certain concepts and frameworks seem to be particularly helpful. One such concept is 'constructionalization' (Traugott and Trousdale 2013: e.g. 22), which refers to the creation of new mental representations (form-meaning pairs) in the grammar of a speaker and has been applied for the process of conventionalization involved in the development of insubordinate clauses (e.g. Evans 2007: 374; Heine et al. 2016). Another concept that has been proposed for the creation of insubordination is that of 'co-optation' (Kaltenböck et al. 2011; Heine et al. 2017). It denotes a cognitive operation which is supposed to precede the constructionalization of insubordinate clauses (Heine et al. 2016), and so-called theticals more generally (for further discussion of the diachrony of insubordination see Section 5). Finally, one framework that seems to be particularly suited to accommodating a phenomenon such as insubordination is that of Construction Grammar (e.g. Goldberg 2006), which sees constructions as conventionalised form-meaning pairings with some idiosyncrasy, where meaning may be attached to the construction as a whole (as discussed in Section 4). It can also account for the close link to related constructions (e.g. subordinate clauses with explicit matrix clause) by its network concept, where constructions are seen as independent, but not isolated entities and as such are linked to other formally or functionally related constructions in a taxonomic network of constructions (e.g. Kaltenböck 2016).

\section{How many types of insubordination are there?}


As a typologically wide-spread phenomenon which potentially involves the whole gamut of subordinate clause types available in a particular language, the phenomenon of insubordination not surprisingly encompasses a considerable number of different forms as well as functions. In terms of form, it is possible to distinguish different types of subordinate characteristics, such as infinitive, participial, or subjunctive inflections of the verb, subordinate word order, and different types of subordinators. In terms of function, Evans (2007), for instance, has identified a wide range of different types which include interpersonal control (e.g. warnings, requests), modal meaning (e.g. epistemic, evidential, deontic, exclamation, evaluation), and signalling presupposed material (e.g. negation, contrast, reiteration) (see Section 4 for discussion). Insubordination is thus marked by considerable variation in both its structure and discourse function.

A further criterion for distinguishing different types of insubordination is its degree of autonomy or independence from the preceding co-text. This question is particularly interesting as it interacts with the scope of dependency and also impinges on the issue of category delimitation more generally (see Kaltenböck, this volume). The insubordinate constructions originally discussed by Evans are typically fully autonomous or self-contained, as illustrated by the example in (7).

(7) ENGLISH (Evans 2007: 380)

If you could give me a couple of 39c stamps please

However, Evans' account already incorporates different degrees of insubordination by virtue of its diachronic perspective, which proposes a historical trajectory from ordinary subordinate clauses with an overt main clause to fully reanalysed and conventionalised main clause structures via two intermediary stages: (i) ellipsis of a fully recoverable main clause, (ii) conventionalized ellipsis with restrictions on permitted reconstructions (see Section 5). Although Evans' definition of insubordination focuses on fully conventionalised main clause uses of formally subordinate clauses, the boundary between conventionalised and nonconventionalised is clearly a fluid one. While thus acknowledging different degrees of dependency in the development of insubordinate constructions, the scope of these dependency relations is generally confined to the domain of the sentence and its missing matrix clause.

By contrast, a wider scope of dependency relations is noted by D'Hertefelt and Verstraete (2014), who distinguish two types of Swedish and Danish at(t) constructions: (i) expressives, which have scope over the sentence as in Evans' account and (ii) elaboratives, which elaborate on something that was said before by the same speaker or a different one. This latter type, illustrated in (8), is thus pragmatically dependent on the preceding co-text. As such, it is seen as falling outside insubordination proper and is attributed to a different mechanism, viz. that of dependency shift (Günthner 1999; Verstraete 2007).

(8) SWEDISH (GSLC, D'Hertefelt and Verstraete 2014: 92)

A: $\quad$ om vi skulle fråga våra eh förstaklassare här om dom vill ha betyg eller inte skulle dom inte fatta vad det handlade om vet inte hur vad betyg eller vad det $e$ (...) så det ju nånting som / andra lägger på

B: $\quad j a$

\begin{tabular}{|c|c|c|c|c|c|}
\hline $\begin{array}{l}\text { att det } \\
\text { COMPit }\end{array}$ & $\begin{array}{l}\text { det } \\
\text { it }\end{array}$ & $\begin{array}{l}\text { kommer } \\
\text { come.PRS }\end{array}$ & $\begin{array}{l}j u \\
\text { PART }\end{array}$ & sen & $\begin{array}{ll}\text { atomatist } & i \\
\text { automatically in }\end{array}$ \\
\hline $\begin{array}{l}\text { skolan } \\
\text { school.DEF }\end{array}$ & $\begin{array}{l}\text { att } \\
\mathrm{COM}\end{array}$ & $\begin{array}{l}\text { man får } \\
\text { Pone get: }\end{array}$ & & $\begin{array}{l}\text { betyg å då } \\
\text { grades }\end{array}$ & $m m$ \\
\hline
\end{tabular}

konkurrensen ännu mera in tror jag va 
'A: if we were to ask our first-graders here if they want to have a diploma or not they wouldn't understand what it was about don't know how what grades or what it is (...) so it's something that / others impose

B: yes

A: that it it then comes automatically in school that one gets grades and then this competition starts even more I think right'

An even wider scope of dependency has been observed by Mithun (2008) in her study of Navajo and Yup'ik markers, which operate over larger stretches of discourse, rather than over the sentence concerned. Mithun (2008: 108) analyses these data in terms of what she calls (functional) extension, whereby patterns of grammatical dependency can be extended from the sentence into larger discourse and pragmatic domains.

Another type of dependency beyond the sentence has been identified in dyadicallydependent clauses, i.e. clauses in spontaneous interaction which can be construed as projections of a complement-taking predicate in a previous turn (Gras 2011, 2013, 2016; Sansiñena 2015; Sansiñena, De Smet, and Cornillie 2015a; Gras and Sansiñena 2015). A typical example are question-answer pairs as in (9), where the complementizer-initial answer can be construed as depending on the matrix clause it means in the preceding question. The scope of the insubordinate clause thus extends over two sentences.

(9) ENGLISH (YCCQA, Sansiñena et al. 2015a: 5)

A: What does it mean if you're getting white hair before 20?

B: That you are the next messiah.

Dyadically dependent clauses such as these are seen as providing a functional motivation for the ellipsis of the main clause, as proposed by Evans' (2007) account (Sansiñena, De Smet, and Cornillie 2015a: e.g. 17). ${ }^{6}$ In a similar vein, various other studies have identified the mechanism of co-construction in interactive discourse as a major factor in the emergence of insubordination in a range of different languages (e.g. Dwyer 2016; Floyd 2016; Evans and Watanabe 2016, Heine et al. 2016, Hilpert 2015).

The typology of semi-autonomous subordination has been further expanded by Van linden and Van de Velde (2014), who draw attention to subordinate dat-clauses in Dutch which are preceded by a single matrix element. Constructions such as these with an incomplete matrix clause are referred to as semi-insubordination. The matrix element may be a noun, as in the example below, or an adjective or an adverb.

(10) DUTCH (CONDIV, Van linden and Van de Velde 2014: 231)

$\begin{array}{lllll}\text { chance dat mijne radio hier } & \text { nog } & \text { opstaat } \\ \text { good.luck COMPmy radio here } & \text { PRT } & \text { be.on.PRS } \\ \text { 'Luckily my radio is still on (here).' } & & & \end{array}$

\footnotetext{
${ }^{6}$ Although Evans (2007: e.g. 418) does not seem to include dyadically construed examples in his category of insubordination, he does acknowledge that "independent clauses may also be a powerful device for integrating successive conversational turns: 'a participant in a conversation may interject, add to, or question the statement of another participant, by using a sentence that is a clause morphologically subordinated [...] to a sentence uttered by another participant."” (Evans 2007: 418).
} 
To conclude, formally dependent clauses used as independent sentences do not represent a uniform, monolithic category. Various types of autonomous and semi-autonomous insubordinate clauses have been identified, in addition to different formal and functional types. This variety raises a number interesting research questions, some of which will be addressed in this volume. First, do all of these types necessarily have to be subsumed under insubordination or can some of them be included in a separate category (see e.g. Mithun, this volume; Kaltenböck, this volume; Sansiñena, this volume). Second, is the relationship between the different types of autonomy a gradient one and how can we best account for such a cline? Third, to what extent is the degree of autonomy linked to different forms and discourse functions? Fourth, have the different types emerged from different source constructions and do they all follow the same pathways of development? (see e.g. Mithun, this volume).

\section{Functions of insubordination}

Evans (2007: 387-423, 2009) sets out heuristically to explore the full functional range of insubordination. As was mentioned in Section 3, he proposes three high-level functions of insubordination cross-linguistically: (i) indirection and interpersonal control, which is found in orders, commands, hints, requests, permissives, warnings and threats as in (11), (ii) modal insubordination, which expresses epistemic, evidential and deontic meanings, as well as evaluation, as in (12), and (iii) the marking of various discourse contexts which involve a high degree of presuppositionality such as negation, contrastive focus constructions, trans-sentential contrast and switch-reference, discourse contrast, reiteration, disagreement with assertions by the previous speaker, and conditions on preceding assertions in interaction, as in (13). This third function, Evans (2007: 368) points out, is related to the adjustment of certain devices which express interclausal relations "to the expression of discourse relations more generally".

(11) ENGLISH (Evans 2007: 393)

If you (dare) touch my car!

(12) ENGLISH (Evans 2007: 403)

That I should live to see such ingratitude!

(13) ENGLISH (Evans 2007: 418)

A: Is it practically impossible to have that [a certain demand curve]?

B: If you have this base.

Let us briefly look at each of the three functions in turn. The first function is related to so-called 'face-threatening acts' (Brown and Levinson 1987), i.e. acts which challenge the face wants of an interlocutor. Evans (2007) argues that insubordinating ellipsis puts the face-threatening act 'off the record' by leaving the implication suspended. He illustrates this first function by providing examples of ellipsed requests and desire predicates, such as the Latin independent subjunctive in (14): This example - originally discussed in Lakoff (1968) - may express an imperative, a wish or a possibility.

(14) LATIN (Lakoff 1968: 158, cited in Evans 2007: 388)

Ven-ias

come-PRS.SUBJ.2SG 


\section{'Come!/May you come!’}

Other structures discussed by Evans in this category include ellipsed enabling predicates, result clauses, and free-standing infinitives.

According to Evans (2007: 393-4), the threatening nature of directive speech acts forces speakers to come up with alternative formulations whose pragmatic force does not carry the negative connotations of existing formulas. However, he also concedes that in certain cases, the pragmatic value of the insubordinate request might not be more polite than that of a more direct form. Similarly, Gras (2011) points out that it is not clear, on the basis of the diachronic motivation proposed by Evans, whether certain insubordinate structures expressing the first function of Evans' typology actually operate as strategies to achieve indirectness.

As for the second function, i.e. modal insubordination, Evans (2007: 394) discusses (i) epistemic and evidential insubordination, involving ellipsed main clauses of reporting, thinking, perceiving and asserting, (ii) deontic insubordination, typically involving complementizers with "additional semantic content, such as showing tense/mood relations between clauses", and (iii) evaluative insubordination, in which the omission of the matrix clause implies amazement or shock. An example of deontic insubordination is given in (15), where the Italian independent subjunctive is used to express hortative meaning:

$$
\text { ITALIAN (Moretti and Ovieto 1979, cited in Evans 2007: 401) }
$$

$\begin{array}{lllllll}\text { Si } & \text { aggiunga } & \text { poi } & \text { che } & \text { l'uomo } & \text { è } & \text { pedante } \\ 3 \mathrm{REFL} & \text { add.SUBJ.3SG } & \text { then } & \text { that } & \text { DEF.man } & \text { is } & \text { pedant }\end{array}$

'And then may it be added that the man is a pedant.'

The third function, finally, implies high levels of presupposed material about the discourse context in which the sentence can occur (Evans 2007: 401). As was mentioned above, there are various types of this use of insubordination, such as the expression of negation, contrastive focus, and reiteration. For negation, Evans (2007: 410-13) proposes that independent negative clauses used to be subordinated to main clauses which carried the assertion, while contrastive focus constructions presuppose a clause that is similar but predicated of another referent. The use of reiteration implies ellipsis of a main clause which reports the speech act of saying or asking. This is illustrated in (16), where the declarative subjunctive in Basque is used to signal a reiterated statement:

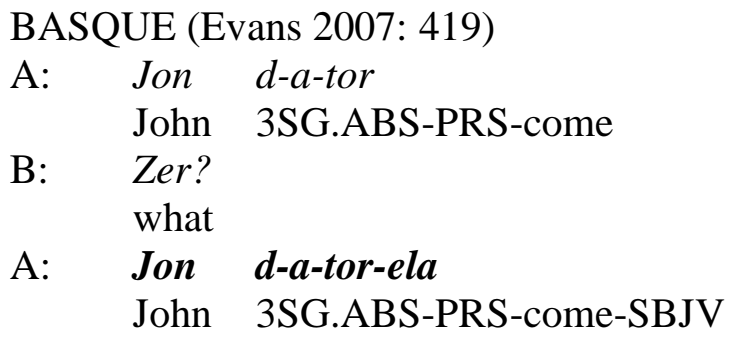

A: 'John's coming. B: What? A: [I said] That John's coming.'

Evans (2007: 422) explains this third function of insubordination by arguing that "grammatical machinery that originally developed around overt relations between a main and subordinate clause $[. .$.$] is subsequently generalized to encode similar relations between the insubordinated$ clause and some other part of the discourse".

The three different functions are, however, not always clear-cut categories. Gras (2011: 352-3), for instance, points out an overlap of the first and second functions of insubordination. 
Evans himself acknowledges that cases of multifunctionality are common and that, despite his distinction of three higher-level functions, in many languages, such as Gooniyandi and Kayardild, one single insubordinate type can take on diverse functions (Evans 2007: 423). Similarly, Sansiñena (2015: 204) shows that the parameters that define Evans' (2007) three higher-level functions are not mutually exclusive and, for Spanish, multi-purpose insubordination is plausible.

Evans' functional classification has been extended in subsequent work on related and unrelated languages from diverse language families. Verstraete, D'Hertefelt and Van linden (2012:142-143), for instance, discuss the functions of dat-constructions in Dutch which expand on - and explain - preceding discourse and establish the functional category of "discursive" insubordination. On the basis of formal and semantic-pragmatic criteria, Sansiñena (2015) identifies three broad construction types for complement insubordination in Spanish: (i) displaced directives, i.e. clauses that express various kinds of deontic meanings, (ii) evaluatives, i.e. clauses that express the speakers' evaluation of a certain state of affairs, and (iii) connectives, i.e. clauses that refer to previous discourse within the same communicative event or in a previous communicative event, and clauses that point to an event that can be directly observed or inferred from the situational context (cf. Gras 2011, 2016).

A number of contributions in Evans and Watanabe (2016) also add functions to the originally proposed list by Evans. Lombardi Vallauri (2016), for instance, argues that Italian 'suspended' or 'free' conditionals can endorse a number of different pragmatic functions ranging from an invitation, an offer and a request, to a protest or refutation of the preceding turn (17) (see also Schwenter 2016 for Spanish and Floyd 2016 for Cha'palaa).

\section{ITALIAN (LIP - Lessico di frequenza dell'italiano parlato, Re11)}

D: signor giudice io ci ho sessantasei anni so' più vecchio pure de lui 'your honour I'm sixty-six I'm even older than him'

\begin{tabular}{|c|c|c|c|c|c|c|}
\hline $\mathrm{E}:$ & $\begin{array}{l}c i \\
\text { there }\end{array}$ & $\begin{array}{l}\text { hai } \\
\text { have:2sg }\end{array}$ & $\begin{array}{l}\text { un } \\
\text { one }\end{array}$ & $\begin{array}{l}\text { anno } \\
\text { year }\end{array}$ & $\begin{array}{l}\text { più } \\
\text { more }\end{array}$ & $\begin{array}{l}\boldsymbol{d} \\
\mathrm{o}\end{array}$ \\
\hline
\end{tabular}

Gras (2016: 139-140) argues for the necessity to distinguish between sentence type, modal and discourse insubordination in order to have a better understanding of the functional range of the phenomenon cross-linguistically. He proposes that sentence type insubordination codifies a speaker position towards the proposition, while modal insubordination expresses a modal evaluation without assigning the speaker a modal position.

Kaltenböck (this volume) argues that insubordinate clauses share many discourse functions with theticals, which relate "to the immediate Situation of Discourse, more specifically the components of Speaker-Hearer Interaction, Speaker Attitude, and Text Organisation", and that semi-insubordination shares with insubordination a similar subjectivising function.

Several authors, including Malčukov (2013) and Mithun (this volume), have argued against there being any functional unity to insubordination, in spite of there being recurring macro-functions, such as context dependency and non-declarative sentence modality, across diverse languages (see D'Hertefelt and Verstraete 2014; D'Hertefelt 2018; Mithun, this volume). Interestingly, within the insubordination literature, there has been a growing interest in exploring the relation between the range of functions and the sources and mechanisms of development of insubordinate constructions. Cristofaro (2016: e.g. 14), for instance, has argued 
against there being a single diachronic source. She posits that an insubordinate clause can have a variety of possible source constructions even if it is related to only one developmental mechanism but that, in many cases, when the discourse function of the construction is ambiguous, it may not be possible to establish which is the mechanism followed. Mithun (this volume) argues that the opposite is also possible, i.e. that only one source construction can be the starting point for the development of diverse insubordinate constructions with diverse functions, via different developmental processes. We can thus argue that insubordination is an umbrella term for a formally-defined phenomenon which encompasses a wide range of constructions with different formal realizations - which have emerged via different mechanisms - and whose functions can be mapped cross-linguistically but with different sets of functions for individual languages.

\section{A challenge for models of diachronic change}

Not only does the grammatical status of contemporary (semi-)insubordinate constructions pose problems for its structural representation, it also challenges extant diachronic hypotheses on the grammaticalization of clause combining (e.g. Beijering and Norde, this volume). That is, insubordination seems to run counter to observed unidirectional tendencies in the domain of grammaticalization and clause combining, according to which looser pragmatic elements become more tightly integrated into syntactic structure. Insubordination, by contrast, concerns developments from subordinate clause to main clause, from morphosyntax to discourse, and (in its initial stage) from grammar to pragmatics (Evans 2007: 429).

According to Evans (2007: 370-5) the diachronic path to insubordination consists of four successive stages from subordinate to insubordinate constructions (see Table 1). The first stage, subordination, includes full constructions with an overt main clause. At the second stage, the overt main clause is ellipsed, but any grammatically compatible main clause can be 'reconstructed' by the hearer. The reconstruction of syntactically permitted main clauses becomes restricted by convention at the third stage. At the fourth stage, the construction acquires a specific meaning of its own, and it may not be possible to restore any ellipsed material.

Table 1. A diachronic model of insubordination (Evans and Watanabe 2016: 3)

\begin{tabular}{|l|l|l|l|}
\hline Subordination & Ellipsis & $\begin{array}{l}\text { Conventionalized } \\
\text { ellipsis }\end{array}$ & $\begin{array}{l}\text { Reanalysis as } \\
\text { main clause } \\
\text { structure }\end{array}$ \\
\hline A & B & C & D \\
\hline $\begin{array}{l}\text { Biclausal } \\
\text { construction, } \\
\text { with subordinate } \\
\text { clause }\end{array}$ & $\begin{array}{l}\text { Ellipsis of main } \\
\text { clause, any } \\
\text { contextually } \\
\text { appropriate material } \\
\text { can be recovered }\end{array}$ & $\begin{array}{l}\text { Restriction on } \\
\text { interpretation of } \\
\text { ellipsed material }\end{array}$ & $\begin{array}{l}\text { Conventionalized } \\
\text { main clause } \\
\text { use of formerly } \\
\text { subordinate } \\
\text { clause }\end{array}$ \\
\hline
\end{tabular}

From this diachronic model, Evans (2007: 386-423) derives a corresponding functional typology of insubordination on the basis of three main types of elided matrix clauses (see Section 4). On this account, insubordinate constructions are the result of ellipsis of (i) predicates of ordering, enablement, permission, desire, etc. (indirection and interpersonal control), (ii) predicates of reporting, thinking, perceiving, asserting, emotion, evaluation (modality), and (iii) 
markers of cleft constructions, from complex bi-clausal constructions (presupposition) (see Mithun 2008: 105-106).

Recently, several studies (see chapters in Evans and Watanabe 2016) have pointed out a number of problems with respect to the application of the (synchronic) definition and diachronic model of insubordination as represented in Table 1. These observations also touch upon questions of delimitation (see Section 2): how to analyse 'lookalike' constructions with either too much or too little elided material (e.g. pseudo-insubordination or semi-insubordinate constructions), or which do not result from main clause ellipsis in a complex clause (e.g. ellipsis of a copula/auxiliary, or no ellipsis)?

Narrog (2016: 278) introduces the notion of 'pseudo-insubordination' to refer to "constructions where the former main clause has already grammaticalized (auxiliarized)". Note that this definition also captures instances of 'semi-insubordination' (see Section 2), which concerns formally subordinate clauses introduced by a single matrix element. The main difference between these pseudo-insubordinates and genuine cases of insubordination is their diachronic development: (gradual) condensation/fusion of the main and subordinate clause versus (abrupt) omission of the main clause (see Table 1).

Another scenario applies to 'lookalike' constructions which fulfill the criteria for synchronic insubordination, but do not meet the diachronic prerequisites. This concerns constructions that derive from ellipsis of a copula or auxiliary instead of ellipsis of a main clause (see Comrie et al. 2016). These lookalike insubordinates may also follow an 'indirect' developmental path with intermediate stages. An example of this is the attested path from "subordinate $>$ periphrastic $>$ independent" in the Tzecic languages (Comrie et al. 2016: 17981). This group of related constructions also includes cases of 'direct insubordination', which do not involve ellipsis of a matrix verb. Instead nominalized forms are directly reanalyzed as finite forms (see Robbeets 2016: 240).

Thus, especially the role of ellipsis as the main mechanism leading to insubordinate constructions has been questioned in recent studies. A number of alternative mechanisms through which insubordinate constructions come into being have been identified in the past decade: extension of dependency markers beyond the sentence level (Mithun 2008), cooptation (Heine et al. 2016), hypoanalysis (Van linden and Van de Velde 2014), dependency shift (D'Hertefelt and Verstraete 2014), and clausal disengagement (Cristofaro 2016). Likewise, it has been argued that insubordinate constructions may derive from multiple source constructions (cf. Cristofaro 2016) or that one source construction may yield multiple insubordinate constructions (see Mithun, this volume).

\section{The present volume}

This volume contains eleven contributions dealing with various aspects of insubordination and related phenomena, as outlined in Section 1. The individual contributions are loosely arranged in three groups with each center around a general topic. The first group (Mithun, Lindström et al., Beijering and Norde, Wiemer) addresses in particular the question of the emergence of insubordination on the basis of diachronic and interactional data. The second group of chapters (Kaltenböck, Sansiñena, Elvira-García) is concerned particularly with questions of delimitation, viz. how to distinguish insubordination from other, related and/or lookalike constructions. The third group of chapters (Von Wietersheim and Featherston, Sánchez López, Struckmeier and Kaiser, Debaisieux, Martin and Deulofeu) addresses a number of issues pertaining to the question of how to account for the peculiar structural features and the special grammatical status of (semi-)insubordinate constructions. The individual contributions are briefly outlined in the remainder of this section. 
In her chapter Sources and Mechanisms Mithun explores the relations between the diversity of functions of insubordination and the diversity of sources and mechanisms of development. The main argument put forward is that the functions of insubordinate clauses are shaped by their structure of origin and the processes they undergo in their historical development. More specifically, the chapter argues that a single source construction can serve as the starting point for the development of different insubordination constructions, via different developmental processes. Mithun analyzes the Mohawk $t s i$ construction and the Navajo $=g o$ construction, which are formally dependent clauses which are now used as independent sentences. She shows that they originate in adverbial clauses from which they developed via different mechanisms, viz. matrix erosion and extension, with their different paths of development leading to different results regarding function and scope.

Lindström, Laury and Lindholm's chapter Insubordination and the contextually sensitive emergence of 'if' requests in Swedish and Finnish institutional talk-in-interaction reports on a synchronic study of Swedish and Finnish insubordinate om and jos 'if' clauses. These constructions may be used as complete directives (requests) without any main clause. On the basis of a multimodal analysis of data from service encounters and medical consultations, they demonstrate that these insubordinate if-requests are the product of the interaction between participants in a conversation. That is, insubordinate conditional requests emerge on-line in response to verbal and non-verbal actions carried out by the addressees of the requests. Their study takes a critical stance towards Evans' (2007) diachronic pathway of insubordination, in particular the role of ellipsis in this model. The data show that if-requests are clearly treated as directives, even in cases without ellipsis when the main clause is subsequently produced. Moreover, insights from language acquisition indicate that insubordinate jos 'if' requests emerge prior to the embedded use of 'if' clauses. On this assumption, it would be odd to argue that a main clause is elided, since the child has not acquired the clause combination yet. These two observations call into question whether the ellipsis hypothesis can adequately account for the insubordinate if-requests in Finnish and Swedish conversation.

In their chapter Adverbial semi-insubordination in Swedish: synchrony and diachrony, Beijering and Norde address the problems that semi-insubordination constructions pose for traditional syntactic analysis and unidirectionality issues in the domain of clause combining and grammaticalization. They show that, although semi-insubordinate constructions are syntactically independent, they are always bound to a preceding proposition in discourse. As such, they occur discourse-internally and function as additional comments or continuations to prior statements and questions. Because of this, semi-insubordination constructions reflect a sequential/incremental dependency at the discourse level. It is precisely these discursive properties of semi-insubordination constructions that cannot be accounted for within previous sentence-based accounts that assume a hierarchical/grammatical dependency between the 'minimal matrix' and the subordinate clause. Moreover, it is argued that contemporary semiinsubordination constructions can only be fully understood in light of their diachronic development. This is illustrated by means of two corpus studies of a particular subtype of semiinsubordination: constructions with subordinate word order introduced by an epistemic adverb. The data support a developmental path in terms of (further) reduction of complex sentence constructions, accompanied by a functional shift of the minimal matrix and subordinate clause, as well as an extension of dependencies at the discourse level.

In his chapter On illusory insubordination and semi-insubordination in Slavic: putting independent infinitives, clause-initial particles and predicatives to the test, Wiemer presents a critical assessment of the notions of insubordination and semi-insubordination and extant hypotheses on the diachrony of these constructions. On the basis of diachronic data, he shows that three apparent '(semi-)insubordinate' constructions in the Slavic languages (independent 
clauses with infinitival predicates, $d a$-headed finite clauses, and predicatives with clausal complements) cannot be regarded as instances of (semi-)insubordination because their development differs from the explanations in Evans (2007) and Van linden and Van de Velde (2014). For these constructions it is shown that they were not derived from more complex structures, but that these structures are diachronically primary to their complex counterparts which have emerged through analogical expansion, syntactic reanalysis and categorial differentiation.

In his chapter Delimiting the class: A typology of English insubordination, Kaltenböck proposes a heuristic for delimiting the class of insubordination and identifying its different subtypes in English. He takes a usage-based approach which involves two interrelated levels of analysis, language usage and syntactic structure, to examine the form-function mismatch typical of insubordinate constructions. Both levels are defined in terms of (in)dependency: syntactic dependence vs. independence on the level of syntactic structure, and pragmatic dependence vs. independence on the usage level. It is argued that the criterion of syntactic independence is crucial in distinguishing insubordination from the category of subordination. In addition, the criterion of syntactic independence emphasizes the commonalities that insubordination shares with a number of other extra-clausal structures (e.g. parenthetical uses of subordinate clauses). The larger category of syntactically independent constructions includes instances of semiinsubordination. Application of the criterion of pragmatic (in)dependence results in a twofold division for subtypes of insubordination: stand-alone insubordination and elaborative insubordination.

The chapter Patterns of (in)dependence by Sansiñena investigates the phenomena of insubordination, semi-insubordination (Van linden and Van de Velde 2014) and causal que in Spanish from an interactional-constructional perspective based on conversational data from the COLA and CREA corpora. The chapter describes in detail the pragmatic, speaker-related functions developed by the Spanish complementizer que when used without a matrix clause, but also delimits the concepts 'subordination' and 'insubordination' when applied to this phenomenon. In doing so, Sansiñena addresses a number of important aspects in the study of (semi-)insubordination, such as the degrees of (in)dependence of these constructions, the distinction of (semi-)insubordination from lookalike structures, as well as the types of possible elements immediately preceding a que-clause and types of relations established between the $q u e$-clause and its preceding element. The analysis in terms of turn-constructional units (TCUs) which takes into account the structure of the turn-intervention offers a new perspective and an alternative to prior sentence-based analyses of these constructions.

In her chapter Two constructions, one syntactic form: Perceptual prosodic differences between elliptical and independent $<\mathrm{si}+V$ indicative $>$ clauses in Spanish, Elvira-García presents the results of two perceptual forced-choice discrimination experiments aimed at testing whether listeners' disambiguation of two apparently identical utterances depends on the intonational realization. The results clearly reflect how speakers perceive the grammatical construction $\langle s i+\mathrm{V}$ indicative $>$ as either elliptical or insubordinate depending on its intonation contour: continuation rise contours are preferably selected for elliptical contexts while rising falling contours are preferably selected for insubordinate refutative contexts. The two experiments were carried out using first original recordings and then synthetically manipulated recordings and efforts were made to consider different varieties of Peninsular Spanish in the design of both tests. Having the same questions and participants for manipulated and nonmanipulated stimuli made it possible to check the manipulation effects in the correctly assigned contours. In line with Elvira-García, Roseano and Fernández-Planas (2017), who show that the distinction between elliptical and insubordinate clauses can be made on the basis of the acoustic prosodic features of the constructions, this chapter demonstrates that the same distinction can 
be detected perceptually. It is further argued that prosody cannot be considered as a mere reflection of a pragmatic function but rather as a means to convey it and that prosody can provide evidence for assigning constructional status to a given structure.

The chapter Does structural binding correlate with degrees of functional dependence? exemplifies how experimental methodology can help improve argumentation in a theoretical debate. Von Wietersheim and Featherston present the results of a series of experiments aimed at finding empirical support for certain theoretically predicted differences in binding behaviour between formally identical but functionally different adverbial clauses introduced by German während 'while', viz. central adverbial clauses (CACs) and peripheral adverbial clauses (PACs). The authors discuss how CACs show formal and functional dependence on their matrix clause being structurally fully integrated into it, while PACs are functionally more independent of their matrix clause and less integrated. By testing the variable 'binding' in a range of adverbial clauses with different degrees of structural integration, such as temporal and adversative clauses with während, it is shown that binding between a main clause and a subordinate clause varies in acceptability, depending on several parameters. The authors compare the binding behaviour of CACs and PACs focusing particularly on the linear order of matrix clause as well as adverbial clause and the relative position of the universal quantifier expression jede $N P$ 'every NP' as binder in either the matrix clause or in the adverbial clause.

In her chapter Optative and Evaluative que 'that' sentences in Spanish, Sánchez López discusses 'exclamative' and 'optative' readings of Spanish main sentences introduced by que 'that' with a subjunctive verb ( $<q u e+\mathrm{VSUBJ}>)$ and argues that the main differentiating factor between them is intonation. It follows that prosody has a semantic effect: while the optative reading is marked with a downward final intonation, the evaluative reading has an upward final intonation. The two readings also differ in the presuppositions they carry: anti-factive for the optative reading and factive for the evaluative reading. The study proposes that the speaker's emotion is evaluated with respect to a bouletic scale related to the desires of the speaker. In this sense, it is argued that intonation marks the orientation of the bouletic scale. Sánchez López proposes that these que-sentences are expressive utterances containing an expressive operator $E X$ with a complex left periphery. In line with the proposal by Rodríguez Ramalle (2008a, 2008b), it is argued that que is located in the Force Phrase in subjunctive sentences.

Struckmeier and Kaiser take a critical stance towards the concept of insubordination in their theoretically-oriented chapter When insubordination is an artefact (of sentence type theories). They question the basic foundation of research on insubordination which is often rooted in generally accepted - but incomplete or empirically inadequate - assumptions about subordination. By putting various sentence types to the test, they show that an illusion of subordination may be created by sentence type theories that define subordination on too narrow an empirical basis. That is, syntactic theories may mislabel sentences as subordinate clauses, which, upon closer inspection, turn out to be not subordinated at all. Subsequently, these mislabelled subordinated clauses (i.e. non-subordinated clauses) may consecutively be mislabelled as insubordinated. The contentious issues with insubordination raised in their chapter are illustrated by means of insubordinate sentences in German as discussed in Evans (2007). They contest Evans' analysis by showing that the alleged subordination of the sentence types in question is an artefact of sentence types theories, and not a property of the clauses themselves. However, they do not claim that insubordination does not exist. Rather they wish to point out that research on insubordination must be carried with empirical caution and should involve careful analyses of individual languages instead of reference to descriptive grammars.

In their chapter Apparent insubordination as discourse patterns in French, Debaisieux, Martin and Deulofeu treat the concept of insubordination as an artefact of sentence type theories (similar to Struckmeier and Kaiser's contribution). This claim concerns two empirical 
situations in French: formally subordinate clauses functioning as independent discourse units (Evans 2007) and peripheral subordinate clauses which display 'main clause features' (Debaisieux 2013). Their analysis is not confined to the level of syntax (unlike Struckmeier and Kaiser's), but extends to the level of discourse. Their approach is based on the fundamental distinction between grammatical syntax and discourse syntax (cf. Blanche-Benveniste 1990). They argue that, by extending syntactic dependency to the level of discourse, candidates for 'insubordination' represent instances of regular syntactic patterns. Their findings are supported by two corpus-based studies on the prosodic, syntactic, semantic, and pragmatic properties of apparent exclamative insubordinates introduced by the subordinating conjunctions si and quand.

\section{References}

Almela Pérez, Ramón. 1985. El si introductor de oraciones independientes en español. LEA: Lingüística española actual 7(1). 5-13.

Beijering, Karin. 2016. Semi-insubordinate at-constructions in Norwegian: formal, semantic and functional properties. Norsk Lingvistisk Tidsskrift 34(2). 161-182.

Beijering, Karin. 2017. Semi-insubordinate dat-constructions in Dutch: formal, semantic and functional properties. Nederlandse Taalkunde 22(3). 333-357.

Bello, Andrés. 1847. Gramática de la lengua castellana destinada al uso de los americanos. Madrid: EDAF.

Bergs, Alexander. 2017. The myth of the complete sentence - a response to Traugott. English Language and Linguistics 21(2). 311-316.

Blanche-Benveniste, Claire. 1990. Le français parlé: Etudes grammaticales. Paris: CNRS.

Boogaart, Ronny. 2015. Een sprinter is enn stoptrein zonder wc. De sturende kracht van taal. Amsterdam: Amsterdam University Press.

Boogaart, Ronny \& Kim Verheij. 2013. Als dát geen insubordinatie is! De pragmatiek van zelfstandige conditionele zinnen. In Theo Janssen \& Jan Noordegraaf (eds.), Honderd jaar taalwetenschap. Artikelen aangeboden aan Saskia Daalder bij haar afscheid van de Vrije Universiteit, 13-28. Amsterdam, Münster: Stichting Neerlandistiek VU, Nodus Publikationen.

Brinton, Laurel J. 2014a. The extremes of insubordination. Exclamatory as if!. Journal of English Linguistics 42(2). 93-113.

Brinton, Laurel J. 2014b. If you choose/like/prefer/want/wish: The origin of metalinguistic and politeness functions. In Marianne Hundt (ed.), Late Modern English Syntax, 271-290. Cambridge: Cambridge University Press.

Brown, Penelope \& Stephen Levinson. 1987. Politeness: Some universals in language usage. Cambridge: Cambridge University Press.

Buscha, Annerose 1976. Isolierte Nebensätze im dialogischen Text. Deutsch als Fremdsprache 13. 27479.

Bybee, Joan. 2010. Language, usage and cognition. Cambridge: Cambridge University Press.

Cable, Seth. 2011. Insubordination in Tlingit: An areal effect? Northwest Journal of Linguistics 5(1). 138.

Cristofaro, Sonia. 2016. Routes to insubordination: A cross-linguistic perspective. In Nicholas Evans \& Honore Watanabe (eds.), Insubordination, 393-422. Amsterdam: John Benjamins.

Comrie, Bernard, Diana Forker \& Zaira Khalilova. 2016. Insubordination in the Tsezic languages. In Nicholas Evans \& Honoré Watanabe (eds), Insubordination, 171-182. Amsterdam: John Benjamins.

Couper-Kuhlen, Elizabeth. 1996. Intonation and clause combining in discourse: The case of 'because'. Pragmatics 6(3). 389-426.

D’Hertefelt, Sarah. 2013. Independent conditional clauses in Germanic languages. Paper given at Complex Sentences International Workshop, Leuven, 16 Nov. 2013 
D'Hertefelt, Sarah. 2015. Insubordination in Germanic: A typology of complement and conditional constructions. Leuven: University of Leuven dissertation.

D'Hertefelt, Sarah. 2018. Insubordination in Germanic. A Typology of Complement and Conditional Constructions. Trends in Linguistics. Studies and Monographs [TiLSM] 318. De Gruyter Mouton.

D‘Hertefelt, Sarah \& Jean-Christophe Verstraete. 2014. Independent complement constructions in Swedish and Danish: Insubordination or dependency shift? Journal of Pragmatics 60. 89-102.

Debaisieux, Jeanne-Marie, Henri-José Deulofeu \& Philippe Martin. 2008. Pour une syntaxe sans ellipse. In Jean-Christope Pitavy \& Michèle Bigot (eds.), Ellipse et effacement: Du schème de phrase aux règles discursives, 225-246. Saint-Étienne: Publications de l'Université de Saint-Étienne.

Debaisieux, Jeanne-Marie. 2006. La distinction entre dépendence grammaticale et dependence macrosyntaxique comme moyen de résoudre les paradoxes de la subordination. Faits de Langue 28. 119-132.

Declerck, Renaat \& Susan Reed. 2001. Conditionals. A comprehensive empirical analysis. Berlin: Mouton de Gruyter.

Deulofeu, Henri-José. 1988. La syntaxe de que en français parlé et le problème de la subordination. Recherches sur le Français parlé 8. 79-104.

Deulofeu, Henri-José. 1999. Problèmes méthodologiques de l'analyse morphosyntaxique de que en français contemporain. Recherches sur le Français parlé 15. 163-198.

Dwyer, Arienne. 2016. Ordinary insubordination as transient discourse. In Nicholas Evans \& Honoré Watanabe (eds.), Insubordination, 183-208. Amsterdam: John Benjamins.

Elvira-García, Wendy. 2016. La prosodia de las construcciones insubordinadas conectivoargumentativas en español. Barcelona: University of Barcelona dissertation.

Elvira-García, Wendy, Roseano, P. \& Fernández Planas A. M. 2017. Prosody as a cue for syntactic dependency. Evidence from dependent and independent clauses with subordination marks in Spanish. Journal of Pragmatics 109. 29-46.

Evans, Nicholas. 2007. Insubordination and its uses. In Nicolaeva, Irina (ed.), Finiteness: Theoretical and Empirical Foundations, 366-431. Oxford: Oxford University Press.

Evans, Nicholas. 2009. Insubordination and the grammaticalisation of interactive presuppositions. Methodologies in Determining Morphosyntactic Change Conference, Museum of Ethnography, Osaka.<http://www.r.minpaku.ac.jp/ritsuko/english/symposium/pdf/symposium_0903/Evans_ handout.pdf $>$.

Evans, Nicholas \& Honoré Watanabe (eds). 2016a. Insubordination. [Typological Studies in Language, 115]. Amsterdam, Philadelphia: John Benjamins.

Evans, Nicholas \& Honoré Watanabe. 2016b. The dynamics of insubordination: An overview. In Nicholas Evans \& Honoré Watanabe (eds.), Insubordination, 1-37. Amsterdam, Philadelphia: John Benjamins.

Evans, Nicholas. 1988. Odd topic marking in Kayardild. In Peter Austin (ed.), Complex sentences in Australian languages, 219-266. Amsterdam: John Benjamins.

Floyd, Simeon. 2016. Insubordination in interaction: The Cha'palaa counter-assertive. In Nicholas Evans \& Honoré Watanabe (eds.), Insubordination, 341-666. Amsterdam: John Benjamins.

Ford, Cecilia E. \& Thompson, Sandra A. 1986. Conditionals in discourse: A text-based study from English. In Elizabeth Traugott et al. (eds.), On conditionals, 353-372. Cambridge: Cambridge University Press.

Ford, Cecilia E. 1997. Speaking conditionally: Some contexts for if-clauses in conversation. In Angeliki Athanasiadou \& René Dirven (eds.), On conditionals again, 387-413. Amsterdam, Philadelphia: Benjamins.

Givón, Tom. 2015. The diachrony of grammar, Vol. 2. Amsterdam: John Benjamins.

Goldberg, Adele E. 2006. Constructions at work: The nature of generalization in language. Oxford: Oxford University Press.

Gras, Pedro. 2011. Gramática de construcciones en interacción. Propuesta de un modelo y aplicación al análisis de estructuras independientes con marcas de subordinación en español. Barcelona: University of Barcelona dissertation. 
Gras, Pedro 2013. Entre la gramática y el discuro: Valores conectivos de que inicial átono en español. In Daniel Jacob \& Katja Ploog (eds.), Autour de Que. El Entomo de Que, 89-112. Frankfurt: Peter Lang.

Gras, Pedro. 2016. Revisiting the functional typology of insubordination: que-initial sentences in Spanish. In Nicholas Evans \& Honoré Watanabe (eds.), Insubordination, 113-144. Amsterdam: John Benjamins. 113-144.

Gras, Pedro \& María Sol Sansiñena. 2015. An interactional account of discourse-connective queconstructions in Spanish. Text \& Talk 35 (4). 505-529.

Gras, Pedro \& María Sol Sansiñena. 2017. Exclamatives in the functional typology of insubordination: evidence from complement insubordinate constructions in Spanish. Journal of Pragmatics 115. 21-36.

Günthner, Susanne. 1999. Entwickelt sich der Konzessivkonnektor obwohl zum Diskursmaker? Grammatikalisierungstendenzen im gesprochenen Deutsch. Linguistische Berichte 180: 409444.

Haiman, John. 1994. Ritualization and the development of language. In W. Pagliuca, (ed.), Perspectives on Grammaticalization, 3-28. Amsterdam: John Benjamins.

Heine, Bernd, Kaltenböck, Gunther \& Kuteva Tania. 2016. On insubordination and co-optation. In Nicholas Evans \& Honoré Watanabe (eds), Dynamics of Insubordination, 39-63. Amsterdam, Philadelphia: Benjamins.

Heine, Bernd, Gunther Kaltenböck, Tania Kuteva \& Haiping Long. 2017. Cooptation as a discourse strategy. Journal of Linguistics 55(4). 813-855.

Hilpert, Martin, 2015. Kollaborative Insubordination in gesprochenem Englisch: Konstruktion oder Umgang mit Konstruktionen? In Alexander Ziem \& Alexander Lasch (eds.), Konstruktionsgrammatik IV. Konstruktionen als soziale Konventionen und kognitive Routinen, 25-40. Tübingen: Stauffenburg.

Huddleston, Rodney \& Geoffrey K. Pullum. 2002. The Cambridge grammar of the English language. Cambridge: Cambridge University Press.

Kaiser, Sebastian. 2014. Interpretation selbständiger Sätze im Diskurs. Syntax und Intonation in Interaktion. Frankfurt, a.M.: Peter Lang.

Kaltenböck, Gunther. 2016. On the grammatical status of insubordinate if-clauses. In Gunther Kaltenböck, Evelien Keizer \& Arne Lohmann (eds.), Outside the clause: form and function of extra-clausal constituents, 341-377. Amsterdam: Benjamins.

Kaltenböck, Gunther, Bernd Heine \& Tania Kuteva. 2011. On thetical grammar. Studies in Language 35 (4). 848-93.

Lakoff, Robin. 1968. Abstract syntax and Latin complementation. Cambridge: The MIT Press.

Langacker, Ronald W. 2000. A dynamic usage-based model. In Michael Barlow \& Suzanne Kemmer (eds.), Usage-Based Models of Language, 1-63. Stanford: CSLI Publications.

Laury, Ritva. 2012. Syntactically non-integrated Finnish Jos 'If'-conditional clauses as directives. Discourse Processes 49 (3-4). 213-242.

Laury, Ritva, Camilla Lindholm \& Jan Lindström. 2013. Syntactically non-integrated conditional clauses in spoken Finnish and Swedish. In Eva Havu \& Irma Hyvärinen (eds.), Comparing and contrasting syntactic structures. From dependency to quasi-subordination, 231-270. Helsinki: Société Néophilologique 86.

Lindström, Jan, Camilla Lindholm \& Ritva Laury. 2016. The interactional emergence of conditional clauses as directives: Constructions, trajectories and sequences of action. Language Sciences 58. 8-21.

Lombardi Vallauri, Edoardo. 2003. "Pragmaticizzazione" dell'incompletezza sintattica nell'italiano parlato: Le ipotetiche sospese. In Leoni F. Albano, F. Cutugno, M. Pettorino \& R. Savy (eds.), Il parlato italiano. Napoli: Atti del Convegno Nazionale (Napoli, 13-15 febbraio 2003), D’Auria Editore, (Cd Rom).

Lombardi Vallauri, Edoardo. 2004. Grammaticalization of syntactic incompleteness: Free conditionals in Italian and other languages. SKY Journal of Linguistics 17. 189-215.

Lombardi Vallauri, Edoardo. 2010. Free conditionals. Linguistica Investigationes 33(1). 50-85. 
Lombardi Vallauri, Edoardo. 2016. Insubordinated conditionals in spoken and non-spoken Italian. In Nicholas Evans \& Honore Watanabe (eds.), Insubordination, 145-169. Amsterdam: Benjamins.

Malčukov, Andrej L. 2013. Verbalization and insubordination in Siberian languages. In Martine Robbeets \& Hubert Cuyckens (eds.), Shared Grammaticalization: With special focus on the Transeurasian languages, 177-208. Amsterdam: Benjamins.

Mato-Míguez, Beatriz. 2014a. Are isolated if-clauses independent clauses? Evidence from spoken British and American English. In Paula Rodríguez-Puente, Teresa Fanego, Evelyn GandónChapela, Sara Riveiro-Outeiral \& $\mathrm{M}^{\mathrm{a}}$ Luisa Roca-Varela (eds.), Current research in Applied Linguistics: Issues on language and cognition, 48-71. Newcastle upon Tyne: Cambridge Scholars Publishing.

Mato-Míguez, Beatriz. 2014b. If you would like to lead: on the grammatical status of directive isolated if-clauses in spoken British English. In Alejandro Alcaraz-Sintes \& Salvador Valera-Hernández (eds.), Diachrony and synchrony in English corpus linguistics, 259-283. Bern: Peter Lang.

Mato-Míguez, Beatriz. 2014c. Looking into the relation between imperatives and isolated if-clauses: Evidence from spoken British and American English. In Esther Álvarez López, Emilia María Durán Almarza \& Alicia Menéndez Tarrazo (eds.), Building interdisciplinary knowledge. Approaches to English and American Studies in Spain, 365-373. Oviedo: AEDEAN \& KRK Ediciones.

Mato-Míguez, Beatriz .2016. The expression of directive meaning: A corpus-based study on the variation between imperatives, conditionals and insubordinate if-clauses in spoken British English. In María José López-Couso, Belén Méndez-Naya, Paloma Núñez-Pertejo \& Ignacio M. Palacios-Martínez (eds.), Corpus linguistics on the move: Exploring and understanding English through corpora, 291-312. Amsterdam \& New York: Brill/Rodopi.

Mithun, Marianne. 2008. The extension of dependency beyond the sentence. Language 84, 1: 69-119.

Montolío Durán, Estrella. 1999. Las construcciones condicionales. In Ignacio Bosque \& Violeta Demonte (eds.), Gramática descriptiva de la lengua española III, 3643-3738. Madrid: Espasa Calpe.

Moretti, Giovanni \& G Orvieto. 1979. Grammatica italiana, vol. 2: Il verbo. Perugia: Benucci.

Narrog, Heiko. 2016. Insubordination in Japanese diachronically. In Nicholas Evans \& Honoré

Watanabe (eds.), Dynamics of Insubordination, 247-282. Amsterdam \& Philadelphia:

Benjamins.

Ohori, Toshio. 1996. Remarks on suspended clauses: A contribution to Japanese phraseology. In Masayoshi Shibatani \& Sandra A. Thompson (eds.), Essays in Semantics and Pragmatics, 201218. Amsterdam: Benjamins.

Ohori, Toshio. 2000. Framing effect in Japanese non-final clauses: Toward an optimal grammarpragmatics interface. Berkeley Linguistic Society 23. 471-480.

Patard, Adeline. 2014. Réflexions sur l'origine de l'insubordination. Le cas de trois insubordonnées hypothétiques du français. Langages 196. 109-130.

Quirk, Randolph, Greenbaum, Sidney, Leech, Geoffrey and Svartvik, Jan. 1985. A Comprehensive Grammar of the English Language. London: Longman.

Robbeets, Martine. 2016. Insubordination and the establishment of genealogical relationship across Eurasia. In Nicholas Evans \& Honoré Watanabe (eds), Insubordination, 209-246. Amsterdam: John Benjamins.

Rodríguez Ramalle, Teresa M. 2008a. Estudio sintáctico y discursivo de algunas estructuras enunciativas y citativas del español. Revista Española De Lingüística Aplicada 21. 269-288.

Rodríguez Ramalle, Teresa M. 2008b. Marcas enunciativas y evidenciales en el discurso periodístico. In Inés Olza, Manuel Casado Velarde \& Ramón González Ruiz (eds.), Actas del XXXVII simposio de la sociedad española de lingüística (SEL), 735-744. Pamplona: Servicio de Publicaciones de la Universidad de Navarra.

Sansiñena, María Sol. 2017. Eliciting evidence of functional differences: The imperative vs. freestanding que-clauses in Spanish. In Daniël Van Olmen \& Simone Heinold (eds.), Imperatives and Directive Strategies, 265-290. Amsterdam: John Benjamins.

Sansiñena, María Sol. 2015. The multiple functional load of que. An interactional approach to insubordinate complement clauses in Spanish. Leuven: University of Leuven dissertation. 
Sansiñena, María Sol, Hendrik De Smet \& Bert Cornillie. 2015a. Between subordinate and insubordinate. Paths toward complementizer-initial main clauses. Journal of Pragmatics 77. 319.

Sansiñena, María Sol, Hendrik De Smet \& Bert Cornillie. 2015b. Displaced directives. Subjunctive freestanding que-clauses vs. imperatives in Spanish. Folia Linguistica 49(1). 257-285.

Schröder, Daniele 2016. That it should have come to this! The challenging phenomenon of insubordination. In Fernanda Pratas, Sandra Pereira \& Clara Pinto (eds.), Coordination and subordination: form and meaning - selected papers from CSI Lisbon 2014, 245-268. Cambridge: Cambridge Scholars.

Schwenter, Scott. 1996. The pragmatics of independent si-clauses in Spanish. Hispanic Linguistics 8. 316-51.

Schwenter, Scott. 1999. Sobre la sintaxis de una construcción coloquial: Oraciones independientes con si. Annuari de Filologia XXI(9). 87-100.

Schwenter Scott A. 2016. Independent si-clauses in Spanish: Functions and Consquences for insubordination. In Nicholas Evans \& Honoré Watanabe (eds), Insubordination, 89-112. Amsterdam: John Benjamins.

Stirling, Lesley 1998. Isolated if-clauses in Australian English. In Peter Collins \& David Lee (eds.), The clause in English: In honour of Rodney Huddleston, 273-294. Amsterdam: Benjamins.

Traugott, Elizabeth Closs. 2017. 'Insubordination' in the light of the Uniformitarian Principle. English Language and Linguistics 21 (2). 289-310.

Traugott, Elizabeth Closs \& Graeme Trousdale. 2013. Constructionalization and constructional changes. Oxford: Oxford University Press.

Van linden, An \& Van de Velde, Freek. 2014. (Semi-)autonomous subordination in Dutch: Structures and semantic-pragmatic values. Journal of Pragmatics 60. 226-250.

Verstraete, Jean-Christophe. 2007. Rethinking the coordinate-subordinate dichotomy. Interpersonal grammar and the analysis of adverbial clauses in English. Berlin: De Gruyter Mouton.

Verstraete, Jean-Christophe, D'Hertefelt \& Sarah, Van Linden, An. 2012. A typology of complement insubordination in Dutch. Studies in Language 36. 123-153.

Vries, Mark de. 2007. Invisible constituents? Parentheses as B-merged adverbial phrases. In Nicole Dehé \& Yordanka Kavalova (eds.), Theticals, 203-234. Amsterdam and Philadelphia: John Benjamins.

Vries, Mark. de n.d. The syntax of nonsubordination: Parenthesis, appositions and grafts. https://www.nwo.nl/onderzoek-en-resultaten/onderzoeksprojecten/i/20/1820.html (9/9/2017)

Weuster, Barbara. 1983. Nicht-eingebettete Nebensätze mit Verb-Endstellung. In Klaus Olszok \& Edith Weuster (eds.), Zur Wortstellungsproblematik im Deutschen, 7-87. Tübingen: Niemeyer.

Yap, Foona Ha, Karen Grunow-Hårsta \& Janick Wrona. 2011. Introduction: Nominalization strategies in Asian languages. In Foona Ha Yap, Karen Grunow-Hårsta \& Janick Wrona (eds.), Nominalization in Asian languages: Diachronic and typological perspectives, vol. 1, 1-58. Amsterdam: John Benjamins. 